\title{
Modified Desarda Repair and Hernioplastia Lichtenstein Repair for Inguinal Hernia.
}

\author{
Pedro Rolando Lòpez Rodrìguez ${ }^{1^{*}}$, Eduardo Garcia Castillo ${ }^{2}$, Olga Caridad Leòn Gonzàlez ${ }^{3}$, Jorge Agustin Satorre Rocha ${ }^{4}$, Luis Marrero \\ Quiala ${ }^{5}$, and Lais Angèlica Ceruto Ortiz ${ }^{6}$. \\ ${ }^{1}$ Consultant Professor in General Surgery, Auxiliary Researcher, General Teaching Hospital, Enrique Cabrera. Havana. Cuba. \\ ${ }^{2}$ Specialist of I Degree in general surgery. Assistant Professor, Havana. Cuba. \\ ${ }^{3}$ Specialist of I Degree in general surgery, Auxiliary Professor and Auxiliary Researcher, Havana. Cuba. \\ ${ }^{4}$ Specialist of I Degree in general surgery and Auxiliary Professor. Havana, Cuba. \\ ${ }^{5}$ Specialist of I Degree in general surgery and Assistent Professor. Havana, Cuba. \\ ${ }^{6}$ Third year resident in general surgery. Havana, Cuba.
}

*Corresponding Author: Pedro Rolando Lòpez Rodrìguez, Consultant Professor in General Surgery, Auxiliary Researcher, General Teaching Hospital, Enrique Cabrera. Havana. Cuba.

Received date: April 14, 2021; Accepted date: April 26, 2021; Published date: May $03,2021$.

Citation: Pedro Rolando Lòpez Rodrìguez, Eduardo Garcia Castillo, Olga Caridad Leòn Gonzàlez, Jorge Agustin Satorre Rocha, Luis Marrero Quiala, and Lais Angèlica Ceruto Ortiz, Modifield Desarda Repair and Hernioplastia Lichtenstein Repair for Inguinal Hernia, J. New Medical Innovations and Research, 2(3): DOI: 10.31579/2767-7370/016.

Copyright: (C) 2021 Pedro Rolando Lòpez Rodrìguez. This is an open-access article distributed under the terms of The Creative Commons Attribution License, which permits unrestricted use, distribution, and reproduction in any medium, provided the original author and source are credited.

\begin{abstract}
Introduction: The objective of this study is to compare the outcomes of Modified Desarda repair no mesh and Lichtenstein repair for inguinal hernia.

Methods: This is a prospective randomized controlled trial study of 1342 patients having 1394 hernias operated from January 2008 to December 2020. 690 patients were operated using Lichtenstein repair and 652 using Desarda repair. The demographie data (Age, Sex), hernia type and location, anesthetic, operative time, postoperative pain and complications were analysed.

Results: There were no significant differences regarding age, sex, location, type of hernia, and pain in both the groups. The operation time was 52 minutes in Modified Desarda group and 42 minutes in the Lichtenstein group that is significant $(\mathrm{p}<0.05)$. The recurrence was $0.0 \%$ in Modified Desarda group and $0.28 \%$ in Lichtenstein group. But, there were 9 cases of infection to the polypropylene mesh in the Lichtenstein group, 2 of this required reexploration. The morbidity was also significantly more in Lichtenstein group (7,6 \%) as compared to Modified Desarda group (3.8\%). The mean time to return to work in the Modified Desarda group was 8.26 days while a mean of 12.58 days was in the Lichtenstein group. The mean hospital stay was $29 \mathrm{hrs}$. in Modified Desarda group while it was 49 hours in the Lichtenstein group in those patients who were hospitalized.
\end{abstract}

Conclusions: The modified Desarda repair scores significantly on Lichtenstein repair in most of all aspects, including reexplorations and morbidity. Modified Desarda repair is a better option compared to Lichtenstein repair.

Keywords: desarda repair; inguinal hernia; lichtenstein repair; randomized trial; hernioplastia; medial hernia; mesh repairs; physiological repair

\section{Introduction}

In 1890, Eduardo Bassini described suture repair for inguinal hernia. This was a massive leap forward and has been the basis of open repair for over 100 years. The surgeon enters the inguinal canal by opening its anterior wall, the external oblique aponeurosis. The spermatic cord is dissected free and the presence of a lateral or a medial hernia is confirmed. The sac of a lateral hernia is separated from the cord, opened and any contents reduced. The sac is then sutured closed at its neck and excess sac removed. If there is a medial hernia, then it is inverted and the transversalis fascia is suture plicated. Sutures, are now placed between the conjoint tendon above and the inguinal ligament below, extending from the pubic tubercle to the deep inguinal ring. The posterior wall of the inguinal canal is thus strengthened.1Over 150 modifications to the Bassini operation have been described with little or no benefit except for the Should ice modification. In this operation, the transversalis fascia is opened by a central incision from deep inguinal ring to the pubic tubercle and then closed to create a double-thick, two-layered posterior wall (double breasting). The external oblique is closed in similar fashion. Expert centres have reported lifetime failure rates of less than 2 per cent after should ice repair but it is a technically demanding operation which, in general hands, gives results identical to the Bassini repair. 
The surgeons use different techniques in Cuba for inguinal hernia repair like Bassini or Shouldice and its modifications or different types of mesh repairs. The standard mesh is not available at many places and it is expensive also. Hernia treatment has become a health problem because of its social, economic and labour implications due to its high incidence in our population [1]. Until recently, the only parameters to be evaluated were recurrence, complication rates etc. Today, other parameters like cost, post-surgery wellbeing and quality of life have gained importance. The demand of general surgeons is to identify operations that are simple to perform without the need for complicated dissection and with low complication and recurrence rates. Avoidance of use of foreign material where possible is a basic surgical principal. The authors read about the Desarda repair which seems be simple in concept, avoids the use of mesh and gives the desired results. This repair is based on the concept of providing a strong and physiologically dynamic posterior wall to the inguinal canal. An undetached strip of the aponeurosis of the external oblique muscle replaces the absent aponeurotic element in the posterior wall and the weakened conjoint muscle receives additional strength from the external oblique muscle to keep it physiologically dynamic [2]. There are still many controversies to answer. Which is the best technique for repair? [3] Is hernioplasty better than herniorrhaphy? Which is the best technique for hernioplasty or herniorrhaphy? Does laparoscopic surgery have a better cost-efficiency than open surgery? Is mesh necessary in all inguinal hernia repairs? The objective of this study is to re-evaluate the Lichtenstein mesh repair and compare it with the novel and "No mesh, physiological repair" described by Modified Desarda Technique.

\section{Method}

This study was designed as a RCT(Randomized Controlled Clinical Trial)among the 1342 patients (652 patients of Modified Desarda's technique \{modification of Desarda's technique by adding Modified Bassini's technique [Darn with continuoussuturing with non-absorbable polypropylenesuture]\} and 690 patients of Lichtenstein procedure alone) of inguinal herniain Surgery Unit 1 \& 2, Enrique Cabrera Hospital, Havana Cuba from a period of January 2008 to December 2020 with a viewto depict the short $\&$ intermediate term (05years) outcomes of newly proposed Modified Desarda's technique in contrast to Lichtenstein procedure. All the patients from both sexes older than 16 years with primary and recurrent inguinal hernias were included. Patients operated on emergency basis were excluded. The diagnosis of inguinal hernia and its type was made by clinical examination. Information was given to the patients as regards the anesthetic procedures. The patient chose type of anaesthesia after discussion with the surgeon. The Randomization was performed using a consecutively numbered, sealed envelope, which was opened, in theatre and all patients having an even number were operated by the Lichtenstein and uneven numbers by the modified Desarda technique. The operating surgeon completed a data sheet. The operating surgeon was at consultant level for all operations.

The evaluator was also a surgeon of consultant level. All patients signed a written informed consent. Approval of the local ethical committee was given prior to the onset of the study. Modified Desarda repair was performed according to the surgical technique described by Dr. Desarda and mesh prosthesis repair was undertaken as described in the textbooks. Prophylactic antibiotic was administered in the operating room before surgery (Cefazoline 1g.) in the Lichtenstein group only. All patients were discharged as soon as their post-surgical recovery allowed, and all patients were instructed to do daily, routine, non-strenuous work after discharge. A non-steroidal anti-inflammatory (Diclofanac) analgesic was prescribed for a period of 5 days and continued if required. The consultants followed all the patients at 8 days, 1 month, 6 months and then yearrequired. The consultants followed all the patients at 8 days, 1 month, 6 months and then yearly thereafter. A data sheet was completed by the operating surgeon including type of hernia (Nyhus classification) [4], anaesthesia, technical details and intra-operative complications. At discharge, further data was added including any early post-operative complications. Patients were asked to complete a pain score on the first, third and fifth day after surgery using a linear analogue scale [5,6]. At first follow up, one month after surgery, further data were collected including time to return to normal activities. The Student $\mathrm{T}$ test was used to compare the independent measures and the Mann Whitney- $U$ test for nonparametric data. The Chi-squared test and Fisher's exact test were used to measure the association between quality variables.

\section{Results}

There was no significant difference in relation to sex, age, location and type of inguinal hernia in both the groups. (Table 1).

\begin{tabular}{|c|c|c|c|c|}
\hline \multirow[t]{2}{*}{ AGE,SEX,LOCATION } & \multicolumn{2}{|c|}{$\begin{array}{r}\text { SURGICAL } \\
\end{array}$} & \multicolumn{2}{|c|}{ ECHNIQUE } \\
\hline & \multicolumn{2}{|c|}{ LICHTENSTEIN GROUP $\mathrm{n}=690$} & \multicolumn{2}{|c|}{ MODIFIELD DESRDA $n=652$} \\
\hline \multirow[t]{2}{*}{ MEDIAN AGE } & \multicolumn{2}{|c|}{57,3 years } & \multicolumn{2}{|c|}{$\begin{array}{c}58,1 \text { years } \\
\end{array}$} \\
\hline & No. & $\%$ & No. & $\%$ \\
\hline \multicolumn{5}{|l|}{ SEX } \\
\hline MALE & 625 & 90,6 & 599 & 92,0 \\
\hline FEMALE & 65 & 9,4 & 53 & 8,0 \\
\hline \multicolumn{5}{|l|}{ LOCATION } \\
\hline RIGHT & 327 & 47,4 & 321 & 49,2 \\
\hline LEFT & 311 & 45,0 & 300 & 46,0 \\
\hline BILATERAL & 52 & 7,6 & 31 & 4,8 \\
\hline \multicolumn{5}{|l|}{ TYPE OF HERNIA } \\
\hline I Y II & 297 & 43,0 & 320 & 49,0 \\
\hline IIIa IIIb & 331 & 48,0 & 297 & 45,6 \\
\hline IV & 62 & $\mathbf{9 , 0}$ & 35 & 5,4 \\
\hline
\end{tabular}

Table 1: Age, Sex, Location and Type of Hernia.

Local anesthesia was used in 294 patients in Lichtenstein group and 399 patients in the Desarda group. All those 707(53.0\%) patients were operated on as outpatient basis without hospitalization. In the remainder of 635 patients who were treated as in-patients, the mean hospital stay was 27 hours in Desarda group and 47 hours in the Lichtenstein group $(\mathrm{p}<0.05)$ (Table 2). 


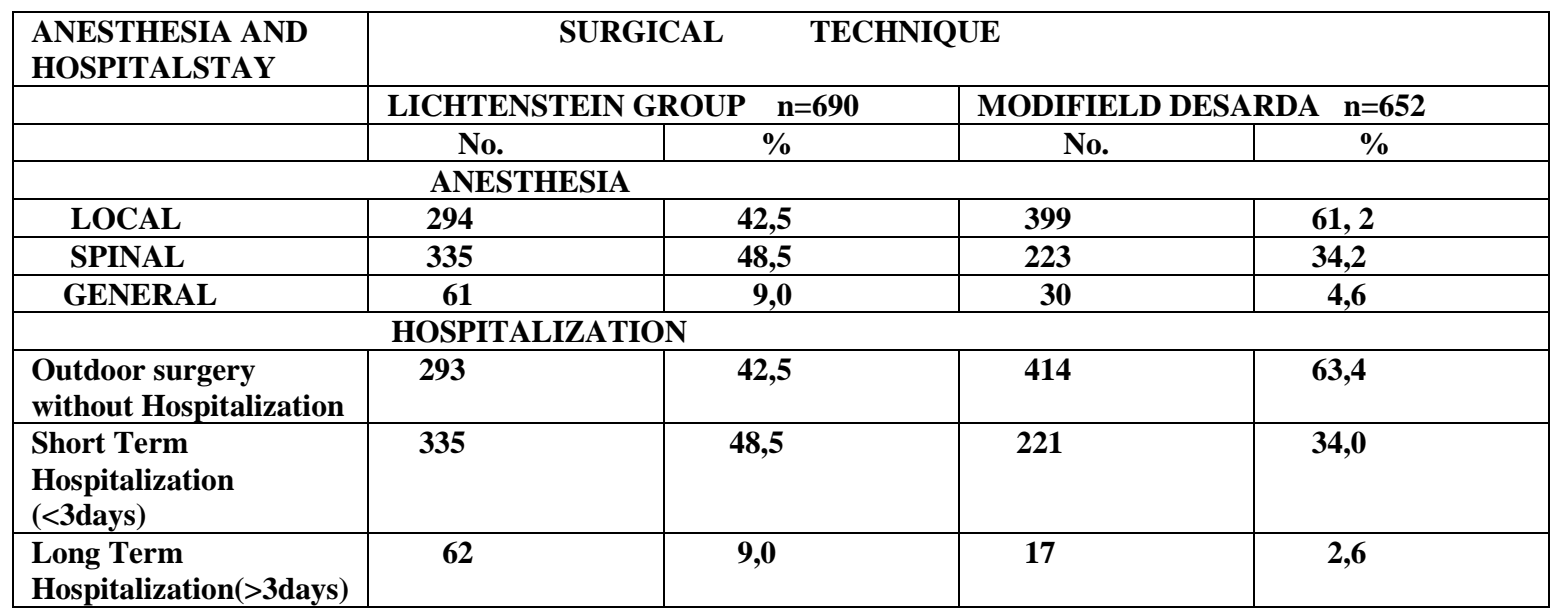

Table 2: Anesthesia and Hospital Stay

Tolerance to local anesthesia was good during surgery in $51,1 \%$ and $56,3 \%$ respectively (NS). The mean duration of surgery was 42 minutes for Lichtenstein and 52 minutes for Desarda group $(\mathrm{p}<0.05)$. Analysis of

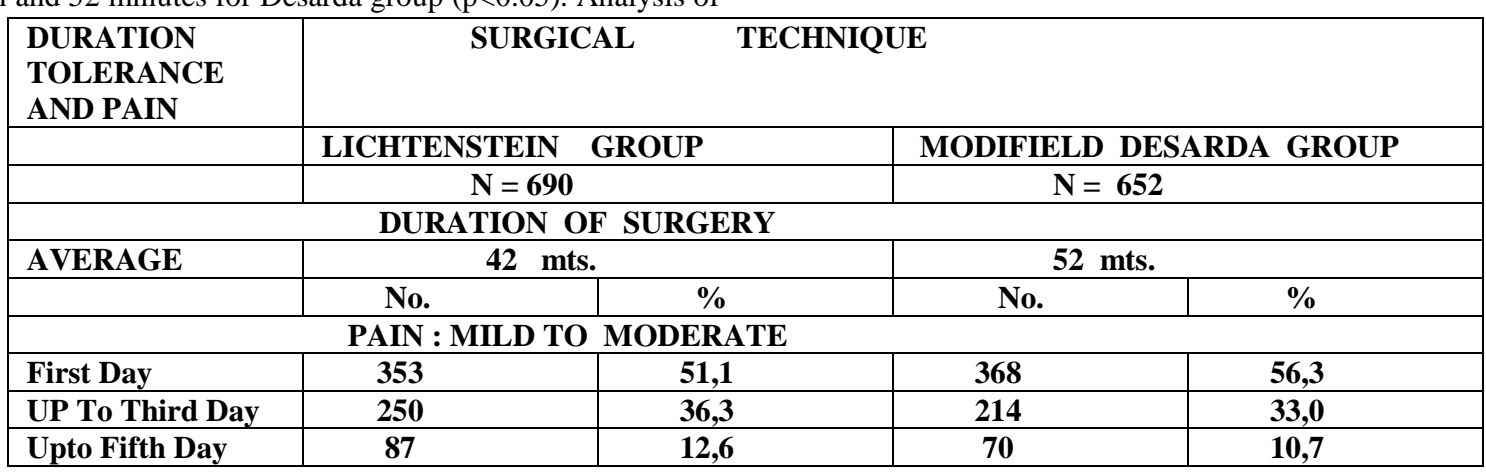

There was no incidence of severe pain or chronic groin pain in both the groups pain scores from day one to day 5 showed no significant difference (Table $3)$.

Table 3: Duration of Surgery and Pain.

There was no incidence of severe pain in any of the groups after three months. The recurrence rate was $0.0 \%$ in the Desarda group, and $0.28 \%$ in the Lichtenstein group (NS). Four patients in the Lichtenstein group required re-exploration and mesh removal for the chronic suppuration. These patients had chronic suppuration, motivated by the rejection of the mesh which caused the mesh to be removed. Thus $0.5 \%$ of patients in the Lichtenstein group required a further surgical intervention for either recurrence or sepsis which was significantly higher than the Desarda group $(\mathrm{p}<0.05)$. All the patients were operated by the same surgeon and his helpers. (Table 4).

\begin{tabular}{|l|c|c|c|c|}
\hline $\begin{array}{l}\text { LICHTENSTEIN } \\
\text { GROUP n=690 }\end{array}$ & $\begin{array}{l}\text { 4 Mesh Removal } \\
\text { for sepsis }\end{array}$ & $\mathbf{0 , 5} \%$ & $\mathbf{2}$ Recurrence & $\mathbf{0 , 2 8} \%$ \\
\hline $\begin{array}{l}\text { MODIFIELD } \\
\text { DESARDA }\end{array}$ & - & - & O Recurrence & $\mathbf{0 , 0 0 \%}$ \\
GROUP n=652 & & & & \\
\hline
\end{tabular}

Table 4: Recurrence and Re-Exploration.

The seroma was the complication that most frequently occurred with 21 patients in both groups (1.5\%). $53(7.6 \%)$ patients developed post-

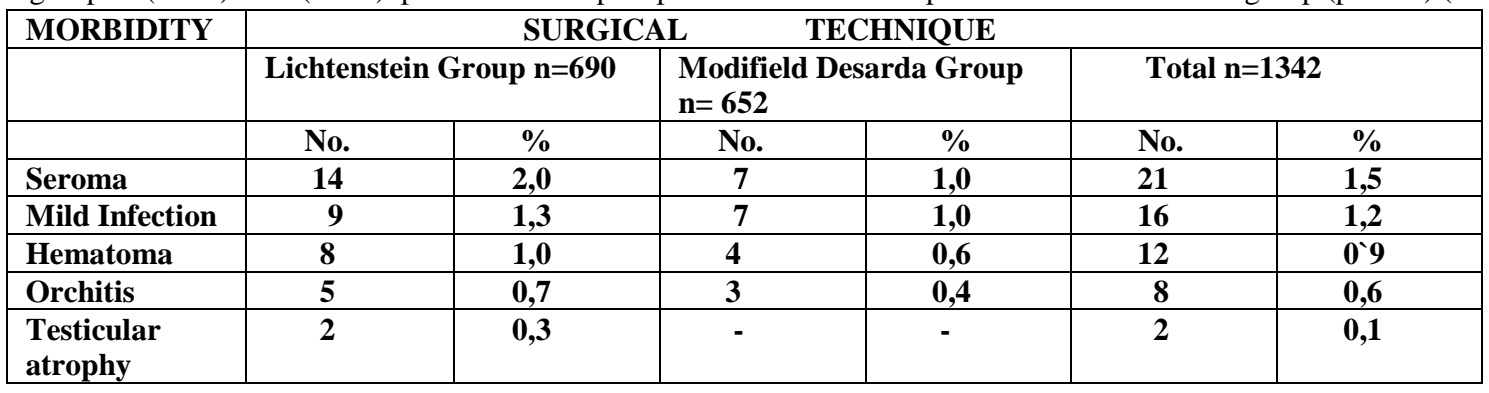




\begin{tabular}{|l|c|c|c|c|c|c|}
\hline $\begin{array}{l}\text { Sepsis without } \\
\text { re-exploration }\end{array}$ & $\mathbf{7}$ & $\mathbf{1 , 0}$ & - & - & $\mathbf{7}$ & $\mathbf{0 , 5}$ \\
\hline $\begin{array}{l}\text { Sepsis with re- } \\
\text { explora tion }\end{array}$ & 2 & $\mathbf{0 , 3}$ & - & - & 2 & $\mathbf{0 , 1}$ \\
\hline Bradycardia & $\mathbf{4}$ & $\mathbf{0 , 6}$ & 4 & $\mathbf{0 , 6}$ & $\mathbf{8}$ & $\mathbf{0 , 6}$ \\
\hline Recurrence & $\mathbf{2}$ & $\mathbf{0 , 2 8}$ & $\mathbf{0}$ & $\mathbf{0}$ & $\mathbf{2}$ & $\mathbf{0 , 1}$ \\
\hline TotaL & $\mathbf{5 3}$ & $\mathbf{7 , 6}$ & $\mathbf{2 5}$ & $\mathbf{3 , 8}$ & $\mathbf{7 8}$ & $\mathbf{5 , 8}$ \\
\hline
\end{tabular}

Table 5: Morbidity

$67,6 \%$ patients returned to work within 8-15 days in the Desarda group with a mean of 13,4 days while $53,2 \%$ patients returned to work within 8-15 days with a mean of 14.5 days in the Lichtenstein group, that is

\begin{tabular}{|l|c|c|c|c|}
\hline $\begin{array}{l}\text { PATIENTS } \\
\text { RETURNED TO } \\
\text { WORK }\end{array}$ & \multicolumn{4}{l|}{ SURGICAL TECHNIQUE } \\
\hline & LICHTENSTEIN GROUP $\mathbf{n = 6 9 0}$ & MODIFIELD DESARDA GROUPn=652 \\
\hline & No. & $\mathbf{5 , 1}$ & $\mathbf{5 2}$ & $\mathbf{8 , 0}$ \\
\hline 1-7 Days & 35 & $\mathbf{5 3 , 2}$ & $\mathbf{4 4 1}$ & $\mathbf{6 7 , 6}$ \\
\hline 8-15 Days & $\mathbf{3 6 7}$ & $\mathbf{4 1 , 7}$ & $\mathbf{1 5 9}$ & $\mathbf{2 4 , 4}$ \\
\hline 16-30 days & $\mathbf{2 8 8}$ &
\end{tabular}

Lichtenstein Group: Mean: 1-7 days: 6,8 days, 8 -15 days: 14,5 days, 16-30 days: 21,3 days. Desarda

Group Mean: 1-7 days: 5,7 days, 8-15 days: 13,4 days, 16-30 days: 18,4 days.

\section{Table 6: Return to Work}

There was no case of chronic groin pain lasting for more than 6 months in either of the groups. Follow up was complete in over $97 \%$ at 1 year, $92 \%$ at 2 years, $89 \%$ at 3 years, $83 \%$ at 4 years, $80 \%$ at 5 years, $80 \%$ at 6 years, $76 \%$ at 7 years, $73 \%$ at 8 years, $72 \%$ at 9 years and $70 \%$ at 10 years with no significant difference between the two operation groups.

\section{Discussion}

Mesh repair is now widely used in the developed world and is often referred to as the gold standard despite the relative shortage of clinical trials comparing mesh with suture repair. The cost of surgery [7] and postoperative morbidity that affects the quality of life are important considerations in inguinal hernia surgery. There is no clear scientific evidence to show that prosthetic mesh repair is superior to non-prosthetic repair in this regard [8]. There are advantages and disadvantages associated with all types of open inguinal hernia repairs. The existing nonprosthetic repair (Bassini / Shouldice) is blamed for causing tension in the tissue and the prosthetic mesh repair is attributed to the known complications of a foreign body. Dr. Desarda sutures a strip not separated from the external oblique aponeurosis between the muscular arch and the inguinal ligament to give a strong and physiologically dynamic posterior wall [9]. This results in a tension-free repair without the use of any foreign body. By being simple to perform, it eliminates the disadvantage of the technical difficulty observed with the ice repair should.

Different studies have tried to give an answer on which of the existing operations is the best for the repair of inguinal hernia [10,11]. The collaboration of EU Hernia Trialist [12] conducted a systematic review of prospective randomized studies and the analysis of the results of these different studies. He showed that the duration of surgery was shorter in hernioplasty in six studies, longer in three and equal in the remaining six. In our group, there was a significant but slight increase in the operating time with the Desarda operation. Postoperative pain after prosthetic mesh repair may be less than after ice repair in case of reduced tension [12,13]. Our results have shown that there are no significant differences between the two groups for pain from the first to the fifth day after surgery. We found no significant differences in the analgesic requirements between the techniques. The overall morbidity was $5.4 \%$, which is similar to the rates described in other studies $(7-12 \%)$ [14]. The morbidity rate was higher after Lichtenstein repair (46 cases, $7.1 \%$ versus $5.4 .0 \%$ in the modified Disarda group). There were 8 mesh infections after surgery in the Lichtenstein group. Two cases required partial excision of the mesh and in case, it was associated with recurrence. The modified Desarda technique has a lower morbidity compared to hernioplasty of mesh. We believe that no cases of recurrences observed in the modified Desarda group were due to the adequate lateralization of the cord and the sufficient narrowing of the inner ring as advised by Desarda.

This was evident in the rescan in those cases that only needed a narrowing of the inner ring with few more points. In patients admitted to the hospital, postoperative stays and the period required to return to normal work after surgery also significantly favored the modified Desarda group. 57 patients of the Lichtenstein group required more than 3 days in the hospital due to local wound complications or for other reasons compared to only 14 patients in the modified Desarda group, a significant difference.

We noticed a marked difference in the type of anesthetic used, $43.6 \% \mathrm{v}$ $63 \%$ for the local, $49.2 \%$ v $37.7 \%$ for the spine and $7.2 \%$ v $3.3 \%$ for the general anesthetic in the modified Disarm group of Lichtenstein. This could affect hospital stay statistics for patients who required hospitalization. The external oblique muscle technique meets all the criteria of modern hernia surgery. It is simple and easy to do. It does not require risky or complicated dissection. There is minimal tension in the suture line. It does not require any foreign material and does not use weak muscle or transverse fascia for repair. It does not use mesh prostheses, so it is cheaper. No foreign body is required in the repair of Desarda, thus avoiding the morbidity associated with foreign bodies, including rejection, infection and chronic groin pain.

Jacek Szopinski, et al. [15] stated in its randomized controlled trial (RCT) that the "Disarm technique" has the potential to increase the number of tissue-based methods available to treat groin hernias. The most obvious indications for the use of the modified Disarda technique include the use in young patients, in contaminated surgical fields, in the presence of 
financial restrictions, or if a patient does not agree with the use of the mesh". Situma, et al. [16] compared the Desarda technique with the modified Bassini technique in their RCT and concluded that there is no difference in the short-term outcome between Desarda and the repair of the modified Bassini inguinal hernia with respect to the resumption of normal gait and pain patterns. Manyilirah [17] concluded in his RCT that the efficacy of the Disarda technique with respect to the early clinical results of hernia repair is similar to that of the Lichtenstein method. However, the operator in this study showed that Desarda repair takes a significantly shorter operating time [18, 19]. Therefore, the authors conclude that modified Desarda repair for inguinal hernia gives the same or better results compared to Lichtenstein mesh repair with a shorter hospital stay, faster recovery and avoidance of related specific complications. With the mesh, while reducing the cost of surgery. It is technically simpler than Shouldice repair and we recommend that surgeons become familiar with this technique [20-23].

In published studies, the recently proposed modified Disarda technique (combined approach of the Desarda and Modified Bassini technique) is a tougher repair for the terms of indirect inguinal hernia of late recurrence in contrast to the Desarda alone procedure [24-27].

\section{Conclusion}

It was demonstrated that the recently proposed Modified Disarming Technique (combined approach of the Desarda and Modified Bassini technique) is a stronger repair for inguinal hernia in terms of late recurrence and that the use of meshes in the Lichtenstein Technique results in greater morbidity, rejections and reexplorations can be found, which cause discomfort to our patients and their families.

\section{Conflicts of interest}

The authors do not declare conflicts of interest.

\section{References}

1. Rutkow MI (1998). Epidemiologic, economic and sociologic aspects of her1. Nia surgery in the United States in the 1900s. Surg. North Am 78: 941-951.

2. López Rodríguez PR, Danta Fundora LM, León Gonzáéz OC, Satorre Rocha JA, Garcia Castillo E .Herniorrafia Mohan P (2018). Desarda Modificada en la reparación de hernia inguinal sin prótesis.Rev Cubana Cir; Vol 57(4):

3. Porrero JL, Bonachía O, López-Buenadicha A, Sanjuanbenito A, Sánchez-Cabezudo C (2005) Reparación de la hernia inguinal primaria Lichtenstein frente a Shouldice. Estudio prospectivo y aleatorizado sobre el dolor y los costos hospitalarios. Cir Esp 77: 5-8.

4. Aragon FJ (2001). Nuevas técnicas protésicas para el tratamiento de la hernia inguinal. Ediciones Avila 2001: 22-23.

5. Price DD, Bush FM, Long S. Harkins SW (1994). A comparison of pain Measurement characteristics of mechanical visual analogue and simple numerical rating scales. Pain 56: 217-226.

6. PorreroJL, Sanchez-Cabezudo C, Lee P (1998). Study of unilateral Post-herniorrhaphy analgesia with local anaesthetic and monitored anaesthesia care. Ambulatory Surg 6: 211-214.

7. 7.-Costos hospitalarios (2005). Comunicación personal. Departamento económico. Hospital Enrique Cabrera. Enero 2015.
8. Porrero JL (1999). El cambio de la cirugía de la hernia en la últimadécada. En: Celdran A., de la Pinta JC, editores. Fundamentos de la hernioplastia sin tensión. Madrid: Fundación Jiménez Díaz: 9-11.

9. Neogi P, Capta V, Tripathi A (2017). A Comparative study of outcome of Lichtenstein repair and Desarda tissue repair in patients of inguinal hernia. Int Surg J; Aug: 4(8): 2693-2699.

10. Simons MP, Kifignen J, Van Geldere D, HoitsmaHFW, Obertop H (1996). Role of the Shouldice technique in inguinal hernia repair: a systematic review of controlled trials and metaanalysis. Br J Surg 83:734-738.

11. McGillicuddy JE (1998). Prospective randomized comparison of the 11. Shouldice and Lichtenstein hernia repair procedures. Arch Surg133: 974-978.

12. EU Hernia Trialist Collaboration (2000). Mesh compared with non-mesh methods of open groin hernia repair: systematic review of randomized controlled trials. Br J Surg 87: 854-859.

13. Kingsnorth AN, Porter Chs, Bennett DH, Walker AJ, Hyland ME, et al (2000). Lichtenstein patch or prefix plug and patch in inguinal hernia: a prospective double-blind randomized controlled trial of short-term outcome. Surgery 127: 276-283.

14. Gilbert AI and Felton IL (1993). Infection on inguinal hernia repair con14. Sidering biomaterials and antibiotics. SurgGynecol 117: 126-130

15. Jacek Szopinski, Stanislaw Dabrowiecki, Stanislaw Pierscinski, Marek15. Jackowski, Maciej Jaworski, et al (2012). Desarda Versus Lichtenstein Technique for Primary Inguinal Hernia Treatment: 3-Year Results of a Randomized Clinical Trial. World J Surg 36: 984-992.

16. S M Situma, S. Kaggwa, N.M. Masiira, S.K. Mutumba (2009). Comparison of Desarda versus Modified Bassini inguinal Hernia Repair: A Randomized controlled trial. East Cent. Afr. j. surg14:70-76.

17. Manyilirah W, Kijjambu S, Upoki A, Kiryabwire J (2012). Comparison of non-mesh (Desarda) and mesh (Lichtenstein) methods for inguinal hernia repair among black African patients: a short-term double-blind RCT. Hernia 16: 133-144.

18. Yousset T, El-Alfy K, Farid M (2015). Randomized Clinical trial of pri18. Mary inguinal hernia. Int J Surg 20: 28-34

19. Dieng M, Cisse M, Seek M, Diallo FK, Tourè AD, et al (2012). Cure des hernies inguinales simples de L' adulte pastie avec L' aponèurose du grand oblique: Technique de Desarda. Emèmoires de L'Acadèmie Nationale de Chirurgie 11: 069-074.

20. Jianxin Z, Dong JW, Zhiyong Z (2013). Desarda inguinal hernia repair and synthetic patch (open VS TEP) hernia repair comparative study. J Chinese Her and abdominal Surg 7: 559563

21. Lòpez Roduìguez PR, Pol Herrera PG, Lèon Gonzàlez OC, Cruz Alon so JR, Rodrìguez Blanco HS (2013). A Randomized Trial Comparing Lichtenstein repair and no mesh Desarda repair for inguinal Hernia: A Study of 1382 patients. East Cent Afr J Surg 2013.

22. Stephen JN and Bruce T (2013). Abdominal wall, hernia and hernia and umbilicus, 22. Bailey and Love's; Short practice of surgery; 26th edn 2013: 957-958.

23. Faruquzzaman, Kumar Mazumder S, Mozammel Hossain S (2016). Dinaipur Med Col J 2016 9: 194-201.

24. Lòpez Rodrìguez PR, Danta Fundora LM, Leòn Gonzàlez OC, Satorre Rocha JA, Garcia Castillo E, Durades Casanova A, Pol 
Herrera P (2018). A Randomized Trial Comparing Modified

Desarda Repair No Mesh and Lichtenstein Repair for Inguinal Hernia ( A study of 1113 Patients ). Journal of Surgery; J surgery an open access journal.

25. Lopez Rodrìguez PR, Leòn Gonzàlez $\mathrm{OC}$, Satorre Rocha Pol Herrera P, Garcia Castillo E, Durades Casanova A, Danta Fundora LM (2018). A Randomized trial Comparing Desarda repair no Mesh and Lichtenstein repair for inguinal hernia ( A study of 2225 patients).Biomedical journal of Scientific \& Technical Research;Vol 6(4).

26. alonso Rodríguez Y, López Martin JE, Gil Soto R, Hernández Nuñez A, Hernández Pérez R (2020). Caracterización de los pacientes con hernia inguinal operados por la técnica de Lichtenstein .Rev Cubana Cir; Vol 59(4):e_1022 (Oct-Dic)

27. Pachauri A, Kumar A (2019). Outcome of Desarda repair incarcerated inguinal hernia experience in University Hospital. Int Surg J; Jun: 6(6): 2084-2087. 